\title{
Sistem Informasi Distribusi Karet Pada PT. REMCO Berbasis Web
}

\author{
Ida Wati ${ }^{1}$, Rusmala Santi ${ }^{2}$, Muhamad Kadafi ${ }^{3}$ \\ idawati@gmail.com ${ }^{1}$, rusmalasanti_uin@radenfatah.ac.id ${ }^{2}$, kadafi_uin@radenfatah.ac.id ${ }^{3}$ \\ ${ }^{1}$ Prodi Sistem Informasi, Fakultas Sains dan Teknologi, UIN Raden Fatah Palembang \\ ${ }^{2}$ Prodi Sistem Informasi, Fakultas Sains dan Teknologi, UIN Raden Fatah Palembang \\ ${ }^{3}$ Prodi Sistem Informasi, Fakultas Sains dan Teknologi, UIN Raden Fatah Palembang
}

Diterima: 4 Juli 2017 | Direvisi: 21 Agustus 2017 | Disetujui: 15 September 2017

(C) 2017 Program Studi Sistem Informasi Fakultas Sains dan Teknologi,

Universitas Islam Negeri Raden Fatah Palembang, Indonesia

\begin{abstract}
Abstrak: Penelitian ini menghasilkan sebuah sistem informasi distribusi karet yang bertujuan untuk menggantikan sistem pencatatan dan pengelolaan data yang dilakukan secara manual ke komputerisasi, guna untuk mengatasi hambatan yang sudah kerapkali terjadi terkait ketidak-mampuan untuk menyediakan informasi yang dibutuhkan secara cepat, akurat dan tepat waktu. Kini dengan sistem informasi tersebut laporan yang dibutuhkan dapat tersedia seketika, seperti: data pelanggan, data pemesanan, stok barang, waktu pengiriman barang, kemana barang akan di kirim, dan laporan ke pada pimpinan/manager. Sistem Informasi Distribusi Karet Pada PT. REMCO Berbasis Web dibangun dengan menggunakan PHP dan MySQL sebagai database-nya dan tools PHPMyAdmin serta metode yang dipakai adalah metode model Rapid Application Development (RAD).
\end{abstract}

Kata Kunci: RAD, Sistem Informasi Distribusi, Berbasis Web

\begin{abstract}
This study produced a rubber distribution information system that aims to replace the system of recording and managing data that is done manually to computerization, in order to overcome obstacles that have often occurred related to the inability to provide needed information quickly, accurately and on time. Now with this information system the report needed can be available instantly, such as: customer data, ordering data, stock items, time of delivery of goods, where the goods will be sent, and reports to the manager/manager. Rubber Distribution Information System At Web-Based PT. REMCO was built using PHP and MySQL as its database and tools PHPMyAdmin and the method used is the Rapid Application Development (RAD) model.
\end{abstract}

Keywords: RAD, Distribution Information System, Web Based

\section{PENDAHULUAN}

Perkembangan teknologi informasi pada aktivitas manusia pada saat ini memang begitu besar. Teknologi informasi telah menjadi fasilitator utama bagi kegiatan-kegiatan bisnis, memberikan andil besar terhadap perubahan-perubahan yang mendasar pada struktur, operasi, dan manajemen organisasi. Berkat teknologi ini, berbagai kemudahan dapat dirasakan oleh manusia. Pengambilan uang melalui ATM (Anjungan Tunai Mandiri), transaksi melalui internet yang dikenal dengan e-commerce atau perdagangan elektronik, transfer uang melalui e-banking yang dapat dilakukan dari rumah, merupakan sejumlah contoh hasil penerapan teknologi informasi.

Website lebih terfokus terhadap sesuatu yang ingin ditampilkan, bisa seputar profil pribadi, profil bisnis, hingga barang-barang dagangan. Akses yang lebih luas, web tidak hanya bisa dikunjungi orang dalam negeri saja, tetapi juga seluruh penjuru dunia, bisa dibayangkan akan seberapa banyak orang mengetahui tentang apa yang dipromosikan/dijual, mencari informasi tentang perusahaan menjadi lebih mudah. Membangun kredibilitas perusahaan di sisi konsumen, dan tentu konsumen baru bergabungan akan lebih percaya. Online 24 jam, 
website lebih meningkatkan keuntungan bisnis perusahaan, tanpa mengenal bats waktu dalam berdagang, maka tidak ada batas juga terhadap keuntungan yang akan kamu peroleh. Internet marketing, sebagai tempat untuk melakukan promosi, dimulai dari produk yang perusahaan hasilkan hingga profit yang didapatkan karena orang lain yang memasang iklan di website. Sebagai penghubung dunia, komunikasi pun tentu tidak hanya mengecil pada satu daerah saja, melainkan menghemat biaya promosi dan komunikasi.

Salah satu contoh perusahaan manufaktur di Palembang ini yaitu perusahaan PT. Remco merupakan suatu industri pengolahan getah para yang berbadan hukum Perusahaan yang beroperasi di Kota Palembang propinsi Sumatera Selatan. Perusahaan yang bergerak di bidang pengolah karet yang mengolah bahan baku karet berasal dari petani karet di kabupaten maupun luar Palembang yang di terima pabrik dalam bentuk slabs, lump, dan cup lump atau lebih di kenal dengan "BOKAR" (bahan olah karet rakyat) menjadi produk setengah jadi yang berkualitas ekspor.

Sistem distribusi karet pada PT. REMCO yang berjalan selama ini masih mengalami masalah, yaitu sulitnya untuk mencari pelanggan baru karena rata-rata pelanggan yang memesan barang adalah pelanggan lama dan pelanggan yang memesan barang menggunakan sistem kontrak. Sistem pemesanan pada PT. REMCO melalui email pada bagian administrasi yang setiap harinya harus di cek dan di print yang nantinya akan diinformasikan ke bagian gudang untuk memproduksi barang yang dipesan oleh pelanggan, dan tidak adanya data pemesanan dari konsumen karena data pemesanan yang digabungkan menjadi satu di laporan produk jadi. Sehingga dari laporan produk jadi tersebut bagian gudang bisa mengetahui berapa banyak produk yang akan dikirim dan kapan produk tersebut akan dikirim.

Pengiriman barang kepada konsumen dilakukan melalui jalur laut yaitu menggunakan kapal tongkang yang berangkat dari Palembang dan akan transit di Singapura setelah dari Singapura baru dikirim ke negara-negara tujuan seperti Amerika, Eropa, Jepang, Belanda dan negara-negara lain. Pengiriman barang memakan waktu selama 3 bulan, setiap pengiriman dilakukan dalam jumlah yang besar dan jika tidak sesuai dengan pesanan atau ada barang yang rusak walaupun hanya satu buah maka semua barang yang dipesan akan dikembalikan semua ke pihak PT. REMCO yang jelas akan membuat perusahaan rugi. Serta tidak adanya laporan penjualan untuk dapat dilaporkan kepada manajer.

\section{METODOLOGI PENELITIAN}

\subsection{Tinjauan Pustaka}

\subsubsection{Sistem Informasi}

Menurut (Sutanta, 2011), sistem informasi merupakan sekumpulan subsistem yang saling berhubungan, berkumpul bersama-sama dan membentuk satu kesatuan, saling berinteraksi dan bekerja sama antara bagian yang satu dengan bagian yang lainnya dengan cara-cara tertentu untuk melakukan fungsi pengolahan data, menerima masukan (Input) berupa data-data, kemudian mengolahnya (proses), dan menghasilkan keluaran (Output) berupa informasi sebagai dasar bagi pengambilan keputusan.

Sedangkan menurut (Sutabri, 2012), sistem informasi merupakan sekumpulan data yang di kelompokan dan diproses sedemikian rupa hingga menjadi satu kesatuan informasi yang saling berkaitan dan saling mendukung hingga menjadi sebuah informasi yang bernilai bagi yang menerimanya.

\subsubsection{Distribusi}

Menurut (Laksana, 2008), distribusi merupakan serangkaian organisasi yang terkait dalam semua kegiatan yang digunakan untuk menyalurkan produk dan status pemiliknya dari produsen ke konsumen. 


\subsubsection{PHP}

PHP merupakan script untuk pemrograman script web server side, script yang membuat dokumen HTML secara on the fly, dokumen HTML yang dihasilkan dari suatu aplikasi bukan HTML yang dibuat dengan menggunakan editor teks atau editor HTML (Sidik, 2006).

\subsubsection{MySQL}

Menurut (Tim EMS, 2014), MySQL merupakan sistem database yang lazim digunakan di lingkungan web, Sistem database yang berjalan di server, cocok untuk aplikasi kecil dan besar, cukup cepat bisa diandalkan dan mudah dipakai.

\subsubsection{Basis Data}

Basis data merupakan sistem terkomputerisasi yang tujuan utamanya adalah memelihara data yang sudah diolah atau informasi dan membuat informasi tersedia saat dibutuhkan. Pada intinya basis data adalah media untuk menyimpan data agar dapat diakses dengan mudah dan cepat (Sukamto, R. A., \& Shalahuddin, M., 2013).

\subsection{Metode Pengembangan Sistem}

Metode yang digunakan untuk membangun sistem ini adalah Rapid Application Development (RAD) adalah sebuah model proses perkembangan perangkat lunak sekuensial linier yang menekankan siklus perkembangan yang sangat pendek. Model RAD ini merupakan sebuah adaptasi "kecepatan tinggi" dari model sekuensial linier dimana perkembangan cepat dicapai dengan menggunakan pendekatan konstruksi berbasis komponen dan dalam periode waktu yang sangat pendek (kira- kira 60 sampai 90 hari). Karena dipakai terutama pada aplikasi sistem konstruksi.

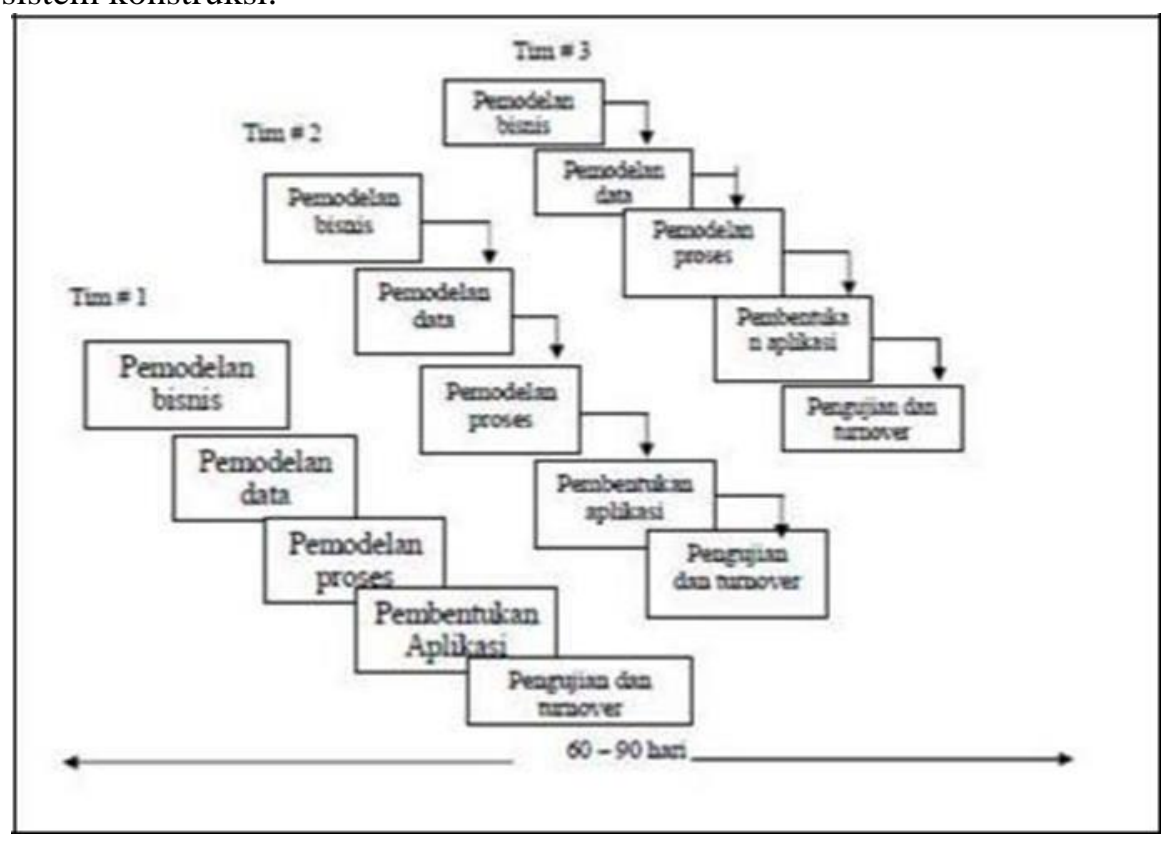

Gambar 1. Model RAD

(Pressman, 2012)

Pendekatan RAD melingkupi fase-fase sebagai berikut:

a. Pemodelan bisnis. Aliran informasi diantara fungsi-fungsi bisnis dimodelkan dengan suatu cara untuk menjawab pertanyaan-pertanyaan berikut: Informasi apa yang mengendalikan proses bisnis? Informasi apa yang dimunculkan? Siapa yang memunculkan? Kemana informasi itu pergi? Siapa yang memprosesnya? 
b. Pemodelan data. Aliran informasi yang didefinisikan sebagai bagian dari fase pemodelan bisnis yang disaring ke dalam serangkaian objek data yang dibutuhkan untuk menopang bisnis tersebut. Karakteristik (disebut atribut) masing-masing objek diidentifikasi dan hubungan antara objek-objek tersebut didefinisikan

c. Pemodelan proses. Aliran informasi yang didefinisikan di dalam fase pemodelan data ditransformasikan untuk mencapai aliran informasi yang perlu bagi implementasi sebuah fungsi bisnis. Gambaran pemrosesan diciptakan untuk menambah, memodifikasi, menghapus, atau mendapat kembali sebuah objek data.

d. Pembuatan aplikasi. RAD mengasumsikan pemakaian generasi keempat. Selain menciptakan perangkat lunak dengan menggunakan bahasa pemrograman generasi ketiga yang konvensional, RAD lebih banyak memproses kerja untuk memakai lagi komponen program yang ada (pada saat memungkinkan) atau menciptakan komponen yang bisa dipakai lagi (bila perlu). Pada semua kasus, alat-alat bantu otomatis dipakai untuk memfasilitasi konstruksi perangkat lunak.

e. Pengujian dan Turnover. Karena proses RAD menekankan pada pemakaian kembali, banyak komponen program yang telah diuji. Hal ini mengurangi keseluruhan waktu pengujian. Tetapi komponen baru harus diuji dan semua interface harus dilatih secara penuh.

\section{HASIL DAN PEMBAHASAN}

\subsection{Tampilan Interface Halaman Utama}

Tampilan halaman utama ini akan muncul ketika ingin membuka sistem distribusi karet pada PT. REMCO pertama kali yang terdapat home, profil, kontak, pendaftaran dan login (pelanggan, admin, bagian gudang, pimpinan).

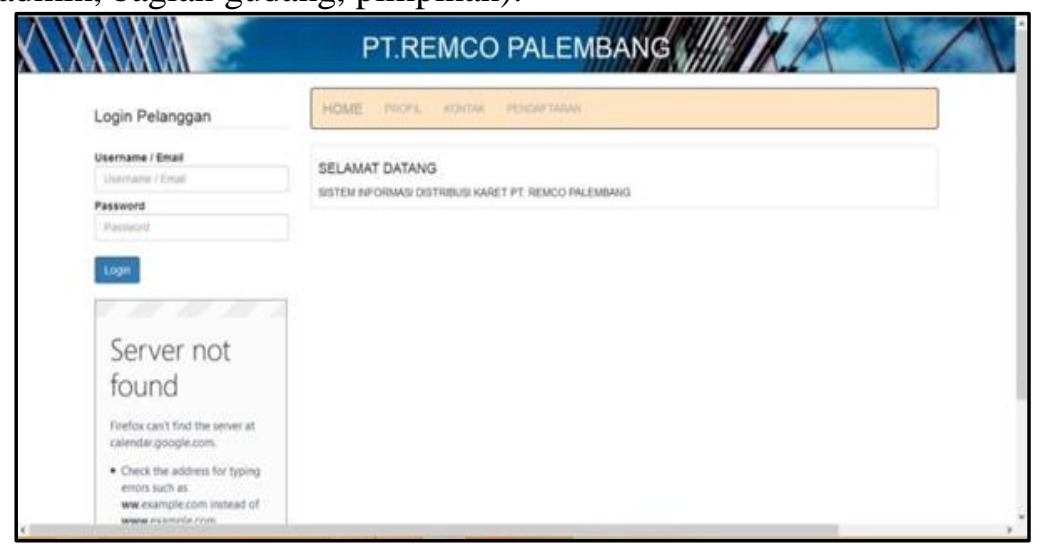

Gambar 2. Tampilan Halaman Utama

\subsection{Tampilan Form Pendaftaran Pelanggan Baru}

Tampilan form pendaftaran pelanggan baru ini akan muncul ketika ingin melakukan pendaftaran pelanggan yakni pelanggan daftar supaya mendapatkan username dan password seperti Gambar 3 dibawah ini: 


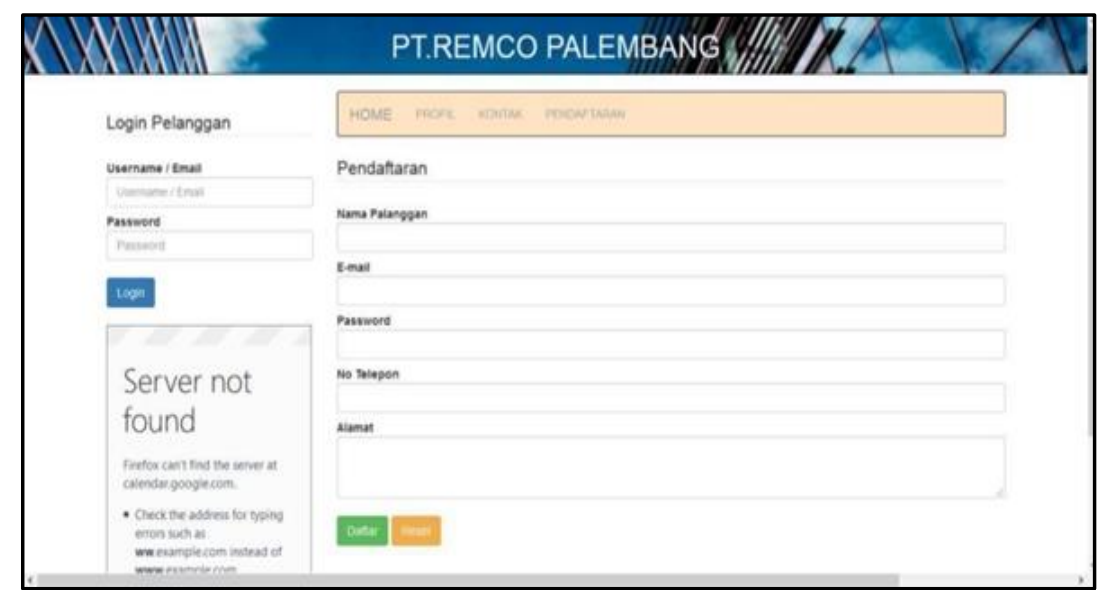

Gambar 3. Tampilan Form Pendaftaran Pelanggan Baru

\subsection{Tampilan Form Konfirmasi Pembayaran}

Tampilan form konfirmasi pembayaran ini berfungsi melihat apakah pelanggan sudah melakukan transaksi pembayaran atau belum jika sudah maka barang akan segera dikirim seperti Gambar 4 dibawah ini:

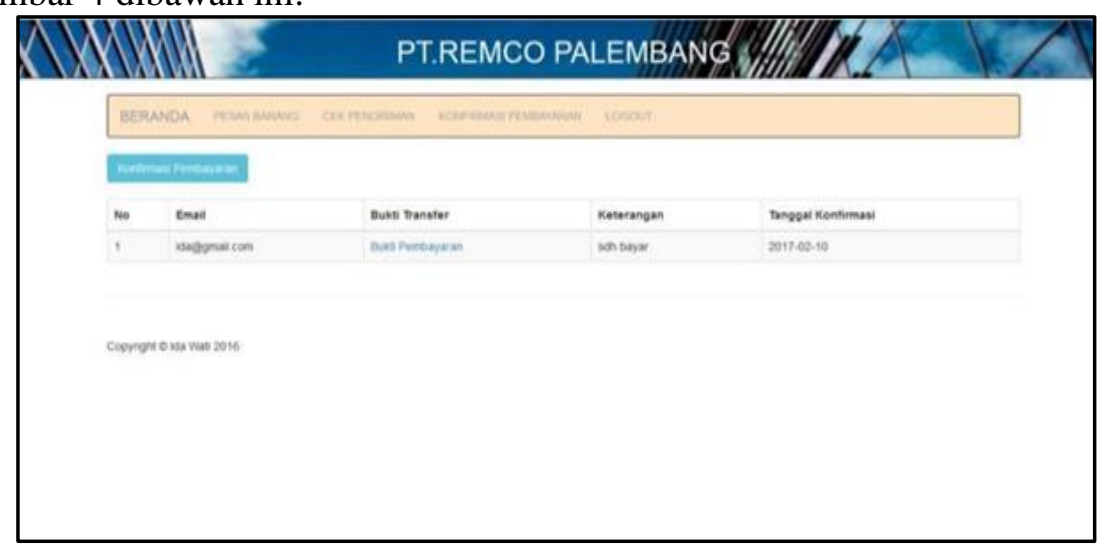

Gambar 4. Tampilan Form Konfirmasi Pembayaran

\subsection{Tampilan Form Laporan Pengiriman}

Tampilan form laporan pengiriman ini berfungsi untuk pimpinan melihat laporan pengiriman barang kepada pelanggan Gambar 5 dibawah ini:

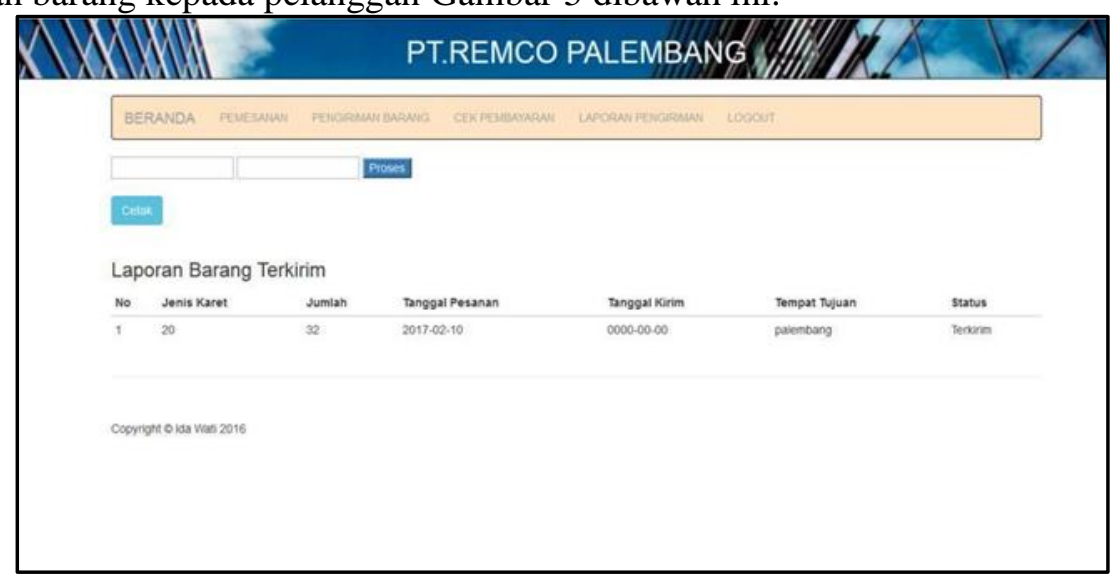

Gambar 5. Tampilan Form Laporan Pengiriman 


\section{KESIMPULAN}

Berdasarkan penelitian yang telah dilakukan dan telah diuraikan dalam skripsi tentang sistem informasi distribusi karet pada PT. REMCO berbasis web. Dengan ini maka dapat disimpulkan beberapa hal sebagai berikut:

1. Dengan adanya sistem informasi distribusi karet ini Memudahkan pelanggan baru dalam melakukan pemesanan barang di PT. REMCO.

2. Dengan adanya sistem informasi distribusi karet ini Memudahkan pihak-pihak PT. REMCO melakukan pengecekan barang, pengecekan pengiriman, pembayaran dan laporan dengan baik. Sehingga tidak perlu waktu lama untuk mencari data yang disimpan dan menghindari kerangkapan data.

\section{DAFTAR RUJUKAN}

Laksana, F. (2008). Manajemen Pemasaran. Yogyakarta: Graha Ilmu.

Pressman, R. (2012). Rekayasa Perangkat Lunak (Pendekatan Praktisi) Edisi 7. Yogyakarta: Andi.

Sidik, B. (2006). Pemrograman Web Dengan PHP. Bandung: Informatika.

Sukamto, R. A., \& Shalahuddin, M. (2013). Rekayasa Perangkat Lunak Terstruktur dan Berorientasi Objek. Bandung: Informatika.

Sutabri, T. (2012). Konsep Sistem Informasi. Yogyakarta: Andi.

Sutanta, E. (2011). Basis Data Dalam Tinjauan Konseptual. Yogyakarta: Andi.

Tim EMS. (2014). Teori dan Praktik PHP - MySQL untuk Pemula. Jakarta: PT. Elex Media Komputindo. 